\title{
THE DOWNTON ABBEY EFFECT IN FILM-INDUCED TOURISM: AN EMPIRICAL EXAMINATION OF TV DRAMA-INDUCED TOURISM MOTIVATION AT HERITAGE ATTRACTIONS
}

\author{
XUERUI LIU* AND STEPHEN PRATT $\dagger$ \\ School of Hotel \& Tourism Management, The Hong Kong Polytechnic University, \\ Kowloon, Hong Kong SAR, China \\ $\dagger$ School of Tourism \& Hospitality Management, The University of the South Pacific, Suva, Fiji
}

\begin{abstract}
This article explores the influence of a television drama on tourist motivation and behavior at a heritage attraction, Highclere Castle in the UK, the setting of the television series, Downton Abbey. The series raises awareness of the attraction and stimulates motivation for traveling. The article identifies specific motivational factors: Prestige, Personalization, Fantasy, and Novelty. Using PLS-SEM, it shows that audience involvement significantly impacts Prestige, Personalization, and Fantasy but impacts Novelty motivation to a lesser extent. The Personalization travel motivation impacts experience outcomes, such as perception of value and satisfaction. Implications for marketing and management practices of heritage attractions are outlined.
\end{abstract}

Key words: Television drama-induced tourism; Heritage attraction; Tourism motivation; Tourist behavior

Introduction

The influence of popular culture in society is increasing (S. Lee \& Bai, 2016; Yildirim \& Aydin, 2012). Popular culture, in the form of motion pictures, has fueled film-induced tourism-that is, the phenomenon of tourists visiting a destination or attraction featured in films or television (Beeton, 2001; Busby \& Klug, 2001; Connell, 2005; Iwashita, 2006). Although the primary purpose of films and television dramas is not to promote film settings as tourist destinations, research has demonstrated that people are often attracted to specific places after they have seen these destinations in films or on television (e.g., Gjorgievski \& Trpkova, 2012; Iwashita, 2008; Pratt, 2015; Rewtrakunphaiboon, 2009; Tooke \& Baker, 1996). A number of destination marketing organizations have strategically used elements of films to promote their destinations, stimulate visitor awareness, and grow 
visitor numbers, mostly notably in New Zealand, South Korea, the UK, and Australia.

Despite increasing research on film-induced tourism, the study of heritage attractions within the context of film-induced tourism is relatively underresearched. Facing a decline in public funding along with an increasingly fierce competition from leisure tourism attractions, heritage attractions are looking for alternative, diverse and innovative ways to attract visitors (Leask, Barron, \& Fyall, 2013). The focus of many of heritage attractions has started to shift from preservation and education to a site's contemporary value and purpose. A number of heritage attractions have gained increased interest as a result of being featured in films or in television dramas. The complex relationship between tourism and heritage resources is a major challenge for heritage management at the heritage attractions (Bąkiewicz, Leask, Barron, \& Rakić, 2017). Given the different aims and management approaches between heritage attractions and other tourism attractions, the application of some visitor-oriented marketing strategies and commercial activities may lead to different outcomes for heritage attractions (Bąkiewicz et al., 2017; Leighton, 2007). Increased interest is often accompanied by a change in visitor profile as the film or television program induces a new group of visitors not previously interested in visiting historical or heritage attractions. This adds to the complexity of heritage attraction management. However, relatively little insight has been gained into these potential dynamics.

Tourism motivation is a complex and dynamic concept. There is debate as to what extent a film or television series drives actual visitation to these sites (Macionis \& Sparks, 2009). There is a call for film-induced tourism research to move from the descriptive to seek explanatory effects. Television series (as opposed to one-off films) can maintain long-term interest through enhanced emotional bonds between audiences and characters, narratives, and places (Connell, 2005). To the best of the authors' knowledge, however, no empirical study to date has examined the effect of television drama on tourism motivation to visit a heritage attraction. While several studies have investigated tourists' behavioral intentions to visit film locations (e.g., Wong \& Lai, 2015; Yen \& Teng, 2015), and their on-site experience (Buchmann, Moore, \& Fisher,
2010; S. Kim, 2010, 2012a, 2012b), this research contributes with new knowledge of heritage attraction and tourism motivation by integrating several facets of the psychological aspects of television drama-induced tourists (i.e., tourists who visited a television drama tourism location) and their experience outcomes at heritage attractions.

This research aims to understand the motivations and behavior drivers of television drama-induced tourists at a heritage attraction, specifically the case of the television drama, Downton Abbey, and its UK setting, Highclere Castle. The study (a) identifies factors of audience involvement related to visiting a television drama heritage attraction; (b) identifies the factors that motivate viewers to visit the television drama heritage attraction; (c) investigates the extent to which audience involvement with a television drama affects their motivations for visitation; and (d) investigates the extent to which motivations for visitation affect experience outcomes of the heritage attraction. This article not only links television dramas and tourism but also provides practical implications for heritage attraction marketing and management. An understanding of emotional involvement or attachment with the television drama and its impact on travel motivation to visit the heritage attraction will not only assist in the protection and conservation of heritage, but also contribute to the development of appropriate tourism products and marketing strategies.

\section{Film and Television Drama-Induced Tourism}

A variety of terms have been used to describe the phenomenon of the interaction between tourism and motion pictures, such as movie-induced tourism (Busby \& Klug, 2001), the media pilgrim on a media pilgrimage (Macionis, 2004), film-induced tourism (Beeton, 2005), television-induced tourism (Connell, 2005; Su, Huang, Brodowsky, \& Kim, 2011), media-related tourism (Busby \& Klug, 2001), and screen tourism (Connell \& Meyer, 2009; S. Kim, 2010; S. Kim \& O'Connor, 2011). Academic research into film-induced tourism started about three decades ago. The first studies on film-induced tourism were based on the concept of hallmark events (Riley \& van Doren, 1992). Motion pictures as a hallmark event, although not their main purpose, can still enhance the awareness, 
attractiveness, and profitability of destinations (Riley, Baker, \& van Doren, 1998), as well as improve destination image (Gkritzali, Lampel, \& Wiertz, 2016). In contrast to hallmark events, which are usually one-off occurrences, motion pictures have relatively long exposure periods of destinations because they are usually released in different mediums, such as cinemas and television (S. Kim, Long, \& Robinson, 2009). Motion pictures also allow greater emotional attachment and engagement with the destination, bringing stronger identification and personal meaning to audiences (Riley et al., 1998). A decline in the popularity of cinema has been accompanied by a growing interest in television dramas. Television dramas, also known as soap operas or miniseries, have become a popular entertainment program genre as well as a powerful channel in distributing popular culture to the international media market (Chang, 2016; S. Kim \& Long, 2012). Television dramas can have more influence on audiences than films due to longer exposure on the screen, a serialization of the storyline, and a stronger sense of identification, empathy, and emotional connection with specific characters over time (Reijnders, 2011).

Popular media include film, television, prerecorded programs, and now digital media, so entertaining content is stronger than ever due to wider accessibility. Compared to traditional media, new digital media has the potential to reach a larger audience. Audiences can access media content at their convenience. They are generally exposed to media content for a longer period compared to watching a single film in a cinema and so viewers may form a relatively stronger attachment to the storylines, destinations, and affinity with specific characters (S. Kim et al., 2009). That content can continuously reinforce the awareness and attractiveness of a film setting or destination, building top-of-mind awareness, as well as intensifying identification, empathy, emotional connection, and social interaction (Su et al., 2011).

Beginning in the early 2000s, a growing body of tourism research on film-induced tourism developed based on case studies that typically focus on the impacts of such phenomena, the characteristics of film-induced tourism, and opportunities for destination marketing and development (Connell, 2012). Some research outlines the negative impacts caused by a sudden flow of tourists to a destination (Connell, 2012). Previous literature found that people are attracted to a specific place after seeing the location on the small or big screen (i.e., film, television, and other digital devices) (H. Kim \& Richardson, 2003; S. Lee, Scott, \& Kim, 2008; Riley et al., 1998). Although a significant number of empirical case studies suggested film as a major motivator for tourists' travel to a destination, it is unclear to what extent tourists are really influenced by the film to visit the destination or attraction. Fernandez-Young and Young (2008) argued that the degree of this screen effect on the propensity to visit should be viewed as fractional rather than absolute. Pratt (2009) used a marketing conversion method to estimate how many people visited tourist attractions in the East Midlands of the UK as a direct result of the film, Pride \& Prejudice. Game (1991) argued that people make sense of visual material through physical engagement with places.

To date, limited research has captured the mental processes behind tourists' decisions to visit filmrelated locations (Connell, 2012). The role film plays as a motivator in influencing tourism destination decision-making to visit a specific location needs to be understood. The conceptual foundation of film-induced tourism is comprised of interconnections between visual media, space, place, and people, so interdisciplinary perspectives are important in establishing the underpinnings of film-induced tourism. This has been recognized by a number of scholars across a range of subdisciplines, such as popular culture (e.g., Kim \& Richardson, 2003; Iwashita, 2006; Shim, 2006;), cultural geography (e.g., Hall \& Page, 2006; Jewell \& McKinnon, 2008; Lukinbeal \& Zimmermann, 2006), and social psychology (e.g., Buchmann, et al., 2010; S. Kim, 2012a; Smith, 2003).

\section{The Viewing Experience of Television Dramas}

Literature covering psychology, media, and communications assists in understanding the emotional experience of viewing a film or a television drama. A variety of components embedded within a television drama, which not only include an interesting plot and characters, but also a complex arrangement of narratives, iconic features, special effects, and soundtracks, create an emotional experience 
and establish a personal connection with a television drama (Chang, 2016; Smith, 2003). Viewers can experience empathy and form an attachment based on a combination of theme, storyline, characters, and landscape to create a sense of place. This affective bond between viewers and a place through shared meanings was termed "topophilia" by Tuan (1974). As with a film, television drama can provide knowledge of a country or region in terms of its nature and culture, which leads to the construction and changes in perceptions of the place (Gkritzali et al., 2016).

S. Kim and Long (2012) suggested four distinctive features of television dramas: serialization, the level of audience exposure and emotional engagement, connections with personal and domestic narration of everyday life, along with being a platform for interpersonal, intercultural, and intertextual discussion. These features are less likely to be replicated in the cinema. These characteristics are adopted for the study of television drama-induced tourism in this article. Through suspense at the end of each episode, as well as progression from episode to episode, television dramas provide audiences with a continual flow of representations and plot development, encouraging them to imagine what might or should come next (Hobson, 2003; Valaskivi, 2000). With regular viewing of television dramas, audiences continuously experience an imaginary sense of intimacy with the onscreen characters, a phenomenon called parasocial interaction (J. Kim \& Rubin, 1997; Schiappa, Gregg, \& Hewes, 2005; Sood, 2002). Through a longer exposure period of television dramas, audiences not only contribute more time to watching episodes on a regular basis, but also invest more emotionally, following the interests of the characters and perhaps even behaviorally respond to the characters ( $\mathrm{S}$. Kim \& Long, 2012). Audience members with a high degree of parasocial interaction may also seek personal relationships with the characters and the places in the stories to confirm their emotional attachment (Giles, 2002; Sood \& Rogers, 2000). This emotional relationship to the television drama is developed and maintained over a period of time, which can be fulfilled by visiting and experiencing the film site (Beeton, 2005; Chen \& Mele, 2017).

\section{What Motivates Tourists to}

Visit a TV Drama Location?

Audiences who watch a television drama do not necessarily decide to travel to the film setting immediately. Their visit is influenced by a number of factors (S. S. Kim \& Kim, 2018). Busby and Klug (2001) stated that film-induced tourists visiting sites after seeing them in films or on television may be motivated by novelty, pilgrimage, escape, or nostalgia. The push-pull motivation framework (Dann, 1977) has been widely adopted in tourism studies and has been recognized as an appropriate method for studying film-induced tourism motivations (Chang, 2016; Macionis, 2004). Many researchers note "film" as an effective motivational pull factor (e.g., Beeton, 2005; Riley \& van Doren, 1992; Tooke \& Baker, 1996), while individuals' internal motivational factors push them into making a travel decision to visit film sites.

Macionis (2004) proposed three pull motivations of tourists to visit a specific film site: place, performance, and personality. "Place" refers to the film location attributes depicted in films, such as spectacular landscapes that are unique and appealing to audiences. "Performance" relates to storylines, atmosphere, or an underlying theme of film, as people can be inspired by specific storylines and genres, as well as the experiences of the characters in order to see where the story develops. The third factor, "personality," relates to the power of favorite film characters, actors, and celebrities. Given the inherent features of television dramas, a range of possible push motivational factors of tourists might include personal connection with the television drama, fantasy, search for a unique or novel experience, and status symbol or prestige. The film location's physical features, events, symbolic content, and characters are given special meaning through the film narrative. Thus, tourists may be drawn to the film sites to fulfill personal motivations. This type of stimuli is similar to "pilgrimage" and "nostalgia" motivations as film-induced tourists "gaze" on film sites (Couldry, 1998; Riley \& Van Doren, 1992). Beeton (2005) suggested "fantasy" as another film-induced tourism motivation because tourists not only look at the scenery at film sites but imagine what is portrayed on the screen. Due to the niche nature of film-induced tourism, visiting 
film locations can be perceived as unique or novel (Macionis, 2004). As such, novelty seeking is also an important motivation associated with viewers of television dramas. Status symbol or prestige has been widely discussed in the tourism motivation literature (Crompton, 1979; Dann, 1981). Returning home with stories of visitation experiences and being able to brag to peers could be a motivational force for visiting television drama locations, especially considering the popularity of television dramas among mass audiences.

\section{Audience Involvement and Television Drama-induced Tourism Motivation}

The idea of "involvement" (i.e., an invisible, active state of interest, arousal, or motivation inspired by a specific situation or a stimulus) can result in a variety of information searching and decision-making behaviors by consumers (Goossens, 2000; Sood, 2002). The hedonic tourism motivational model developed by Goossens (2000) explains the interrelationships among push and pull motivational forces, travel information processing, emotional response, and behavioral intention. This model can be used to understand and predict the hedonic and motivational reactions of tourists towards destination promotional stimuli in the travel choice process. As shown in Figure 1, the left side of this "disposition-stimulus-response" model displays "push factors" in terms of inner desires and needs of customers. The right side presents destination attributes confronted by the tourists, which are pull factors or marketing stimuli such as the supply of tourism services, facilities, brands, advertising, and symbols of the destination. The push and pull forces combine together in the mind of the consumer into an involvement concept, which is an unobservable state of motivation, arousal, or interest (Havitz \& Dimanche, 1990). This involvement concept translates to hedonic responses that integrate consumers' mental imagery and emotions (Van Raaij \& Crotts 1994), which then leads to motivation.

Audiences' emotional attachment to popular media subsequently affects their perceptions and images of the destination setting (S. Kim, 2012a; S. S. Kim \& Kim, 2018; Riley et al., 1998). Each tourist's perception of the destination is highly subjective, personalized, and exclusively based on individuals' characteristics, sensations, and imagination as well as the interpretations and memories constructed through precious viewing experience. A number of pull motivational forces associated with television drama locations as well as a variety of push motivational factors in terms of audiences' responses are involved in the viewing experience. This influences travel intentions and motivations, and affects decision-making when choosing a travel destination.

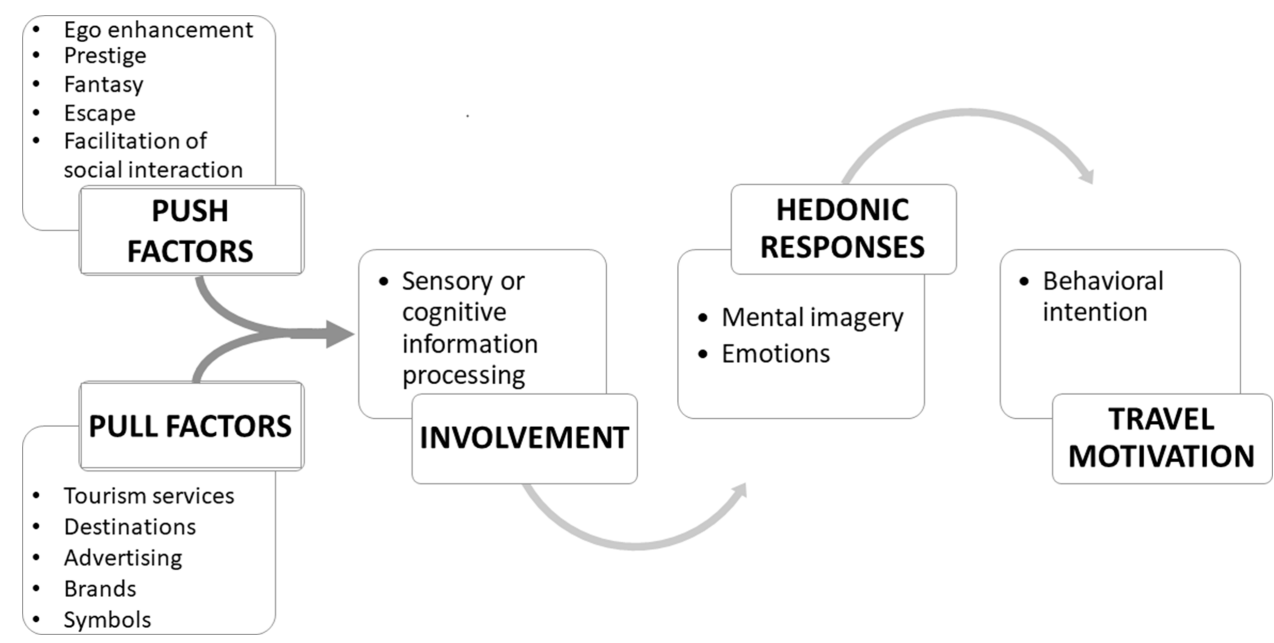

Figure 1. Hedonic tourism motivational model (Goossens, 2000). 
Sood (2002) provides an appropriate definition of audience involvement as the level to which the audience engages in parasocial interaction with, and reflection upon, a certain media program. This leads to an evident and decisive behavior change. The concept of audience involvement is multidimensional rather than one dimensional. Sood (2002) divided audience involvement into two main dimensions: reflection, containing critical and referential reflection, and parasocial interaction, involving cognitive, affective, and behavioral participation with mass media. This multidimensional concept is essential to connect push and pull motivational factors, which then influence various aspects of television drama-induced tourists' behaviors (S. Kim \& Long, 2012).

The empirical application of this model to drama-induced tourism has been relatively limited. One exception is S. Kim (2012a), who investigated the extent to which audience involvement with a serialized television drama affects on-site tourism experiences at film locations using Sood's (2002) audience involvement concept. However, in that study, cognitively oriented involvement was not found to influence audiences' viewing experiences and hence did not affect their subsequent tourism experiences.

This article conceptualizes the concept of audience involvement in the context of television drama as being composed of three main elements: (a) referential reflection, (b) emotionally or affectively oriented interaction, and (c) behaviorally oriented interaction.

Referential reflection refers to the extent to which audience members relate television drama to real life. The time intervals between episodes prompt speculation and discussion about the program in social networks and connect the television drama to daily experiences and problems of the viewer (S. Kim \& Long, 2012). The role of television dramas as a platform of interpersonal and intertextual discussions among audiences promotes referential reflection (Sood, 2002), which potentially shapes postviewing behaviors including travel motivation.

Referential reflection is discussed from four different motivations to travel: for prestige, personalization (or the personalizing of the television drama to the viewer's life), fantasy (the viewer's life being transferred to the television drama), or novelty factors. This leads to the following hypotheses:

H1a: Referential reflection on a television drama is positively related to a motivation to travel to the television drama-based location for Prestige reasons.

H1b: Referential reflection on a television drama is positively related to a motivation to travel to the television drama-based location for Personalization reasons.

H1c: Referential reflection on a television drama is positively related to a motivation to travel to the television drama-based location for Fantasy reasons.

H1d: Referential reflection on a television drama is positively related to a motivation to travel to the television drama-based location for Novelty reasons.

The second element of audience involvement to be investigated is emotionally or affectively oriented interaction with the television drama. This refers to the extent to which audience members identify with the characters or other features of the television drama, such as a location or a community. Emotional interaction includes both identification with and affection for the characters and also emotional reaction to the production values of the television drama (S. Kim \& Long, 2012; Sood, 2002; Sood \& Rogers, 2000). The imaginative and emotional involvement of audiences forms personalized memory and symbolic dimensions of touristic spaces and plays an essential role in affecting attitudes toward portrayed locations (S. Kim, 2012a; Su et al., 2011). Personal emotional involvement may further influence audiences' intention to visit television drama locations. This leads to the following hypotheses:

H2a: Emotional involvement with the television drama is positively related to a motivation to travel to the television drama-based location for Prestige reasons.

H2b: Emotional involvement with the television drama is positively related to a motivation to travel to the television drama-based location for Personalization reasons. 
H2c: Emotional involvement with the television drama is positively related to a motivation to travel to the television drama-based location for Fantasy reasons.

H2d: Emotional involvement with the television drama is positively related to a motivation to travel to the television drama-based location for Novelty reasons.

The third element of audience involvement to be investigated is behaviorally oriented interaction. This refers to the extent to which audience members talk about the characters or actors in a television drama, or rearrange their schedules to make time for viewing the television drama. This imagined sense of intimacy may lead to actively seeking personal contact with the media figures and places, which in turn has consequence for television drama-induced tourism motivation (Giles, 2002; Sood $\&$ Rogers, 2000). The following hypotheses will be tested:

H3a: Behavioral involvement with the television drama is positively related to a motivation to travel to the television drama-based location for Prestige reasons.

H3b: Behavioral involvement with the television drama is positively related to a motivation to travel to the television drama-based location for Personalization reasons.

H3c: Behavioral involvement with the television drama is positively related to a motivation to travel to the television drama-based location for Fantasy reasons.

H3d: Behavioral involvement with the television drama is positively related to a motivation to travel to the television drama-based location for Novelty reasons.

\section{Travel Motivation and Experience Outcomes}

A number of tourism studies have examined what drives tourists to film sites and what their onsite experience is once there: how tourists perceive, interact, and associate with the location. Literature suggests that films or television dramas play a significant role in not only creating awareness, developing expectations of destinations, motivating visits, but also affecting activities and routes for film-induced tourists while at the destination (Croy \& Heitmann, 2011; Sellgren, 2011).

Macionis (2004) provided a framework to describe three categories of film-induced tourists with different travel motivations and behaviors while at a film location. Serendipitous film tourists are tourists who just happen to be in a place portrayed in a film and may not take part in filmbased tourism activities. General film tourists are not particularly motivated by a film but still take part in film tourism activities during their trips. Specific film tourists visit places that they have seen on the screen and this is the primary reason for traveling. Specific film tourists actively seek out those places while at a destination and relive their favorite scenes. Such travel behavior can be regarded almost as religious pilgrimages (Beeton, 2005). The more a tourist is interested in and attracted by a film to a destination, the greater the role of push factors in travel decisionmaking (Sellgren, 2011). For film-induced tourists, visiting and experiencing a selected film site represents a personal reward and leads to higher level of self-actualization. In comparison to those who incidentally come across a place, they tend to be less concerned about destination authenticity. Instead, they place more emphasis on film authenticity (Croy \& Heitmann, 2011). Since the views, storylines and characters in the film are kept in people's memories as they have seen and experienced them, the desire for location authenticity is replaced with personal meaning and fantasy.

Several studies have investigated how the location itself shapes tourist activities and experiences undertaken at the film sites. Television drama contextualizes tourists' expectations concerning what they might experience on site (S. Kim \& Long, 2012). Overall satisfaction with a heritage attraction, comparing the experience of this attraction with both expectations and other similar attractions and being worthy of the visitors' time and effort are all measures of visit outcomes of the heritage attraction experience. Given the above literature, this article proposes the following hypotheses to test the relationship between the elements of motivation to travel (Prestige, Personalization, Fantasy, Novelty) and the visitor experience once at the location. 
H4a: Travel to television drama-based locations motivated by Prestige reasons is positively related to Experience outcomes.

H4b: Travel to television drama-based locations motivated by Personalization reasons is positively related to Experience outcomes.

H4c: Travel to television drama-based locations motivated by Fantasy reasons is positively related to Experience outcomes.

H4d: Travel to television drama-based locations motivated by Novelty reasons is positively related to Experience outcomes.

Building on previous research and hypotheses developed above, this article presents a consolidated model, as shown in Figure 2. In this model, the television drama can be considered an information source, which has a number of motivational pull factors such as place, performance, and personality. Through audience engagement and involvement with the television drama (the stage of information processing), the pull factors (the television drama destination attributes), as well as push factors (audiences' inner desires, such as prestige, personalization, fantasy and novelty), can influence audiences' experience at the television drama location. As a result, audience involvement influences motivation to travel which in turn drives experience outcomes (such as overall satisfaction, perceived value, expectations, and comparative performance) with the television drama heritage location.

\section{Case Study and Research Method}

Case study research is a useful method of understanding a general theme in a specific context. For this case study research, Highclere Castle, a heritage attraction located in the UK, is the setting for a television drama. Since its premiere in September 2010, Downton Abbey has been broadcast in more than 200 countries or regions. National Broadcasting Company, Universal, estimated that more than 120 million worldwide viewers have watched Downton Abbey, making it one of the most watched television dramas in the world (Egner, 2013) and Britain's most successful television export. Highclere Castle, the main setting of Downton Abbey, has been used in the "Great Britain Campaign" by Visit Britain to promote Britain's heritage, culture, and countryside (Visit Britain, 2014). In 2013, Downton Abbey directly resulted in 105,904 overseas tourist nights in Britain, contributing over $£ 10.5$ million in additional visitor spend (Visit Britain, 2014). This popular television drama has spurred what the media calls the "Downton Effect," having a considerable impact on several British industries, such as property prices, luxury clothing, and British butlers.

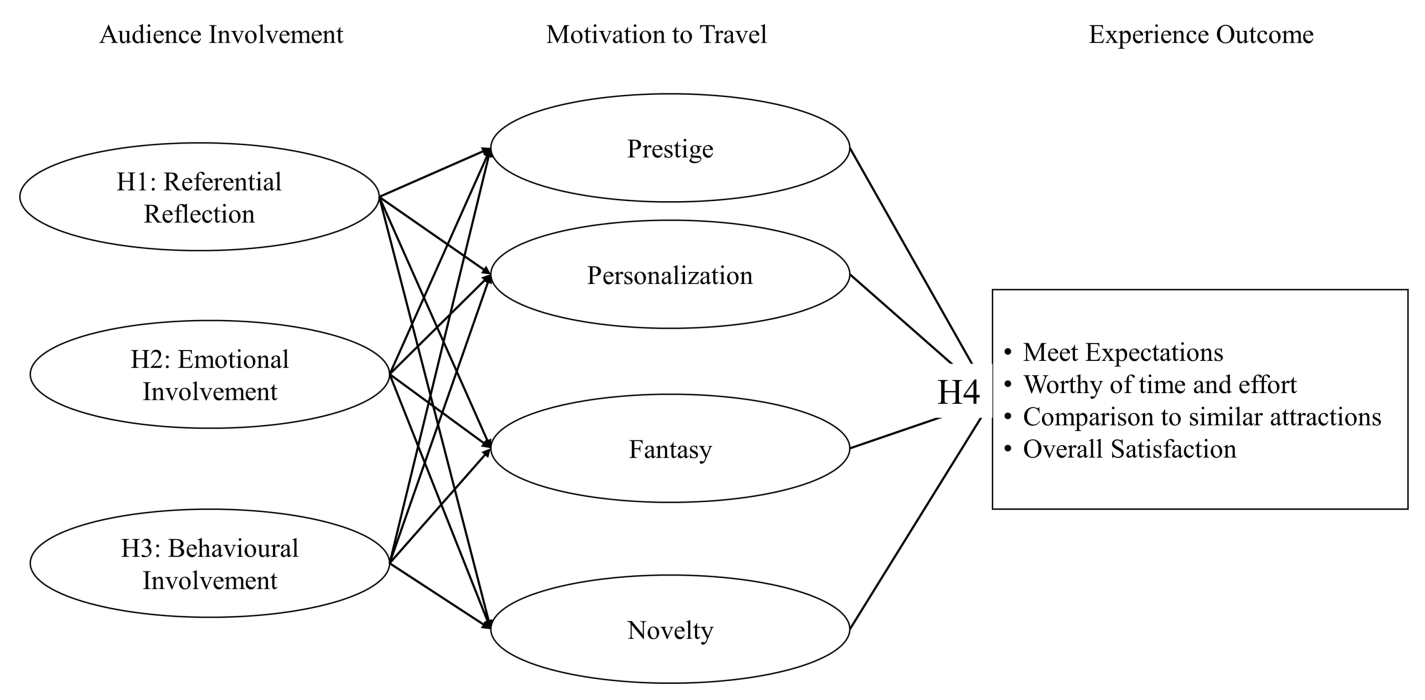

Figure 2. Hypothesized television drama-induced tourist model. 
To answer the research objectives of this study, a questionnaire survey was employed to collect primary data relating to audience involvement, television-induced tourism motivation, and general travel behavior. The survey was conducted in English. The questions referring to audience involvement were derived from S. Kim's (2012a) study. Sood's comprehensive audience involvement scale was chosen because the validity and reliability of the scale were tested in Sood's (2002) study. A total of 14 items were used for this survey. Every item was presented as a definitive statement followed by options that indicate varying degree of agreement with that statement. Respondents were asked to rate their level of agreement to these items on a 5 -point Likert-type scale, where 1 is Strongly disagree and 5 is Strongly agree. Similar to Macionis and Sparks' study (2009), 25 question items were adapted and related to tourists' motivations to visit Highclere Castle inspired by Downton Abbey. A 5-point Likert scale was chosen to enable a comparison between Macionis and Sparks' study (2009) and results from this study. Four experience outcome questions were asked of visitors to Highclere Castle. These questions assess their experience of the visit and specifically capture overall satisfaction; if the visit was worth the time and effort; ability to meet expectations; and comparison to other similar heritage attractions (all assessed on a 5-point Likert scale).

Prior to administering the main survey, the questionnaire was pilot tested among 15 respondents who reported visiting a film setting before, in order to ensure the validity of the content of the questionnaire and the reliability of the measurement scale (Saunders, 2012). This study focuses on tourists to Highclere Castle who had watched Downton Abbey before the visit as the research aims to understand the extent to which the film or television series drives actual visitation to the sites. The first part of the questionnaire asks if the respondent had watched Downton Abbey before visiting Highclere Castle, while the second part of the survey asks about respondents' involvement with Downton Abbey, the main reasons for visiting Highclere Castle, and their general travel behavior. Finally, sociodemographic characteristics of the participants are captured, including gender, nationality, age group, and educational level.
A convenience sampling method was used as the chance of each population's element being selected could not be predetermined or known (Saunders, 2012). Additionally, it was not physically possible to control visitors' passage. The interviewing technique was an in-person intercept survey conducted at the entry and exit point of Highclere Castle where the interviewer approached every fifth person who entered the heritage attraction. Interviewing varied by the time of day and day of the week to minimize potential biases. Potential respondents were informed of the purpose of the survey, told that the interview was for research purposes only, and informed that they could withdraw from the survey at any time. Potential respondents were told the approximate length of the survey and assured that all information they provided would remain confidential. A total number of 150 printed questionnaires were distributed to both domestic and international tourists at Highclere Castle in July 2014. Six respondent were omitted because missing data exceeded $25 \%$ of the total questionnaire (Sekaran, 2003). There were 144 usable responses for data analysis. Out of the 144 visitors surveyed, $25(17.4 \%)$ had not seen the series. These visitors are excluded from the following analysis, leaving 119 for further analysis.

To investigate the extent to which audience involvement with a television drama affects their motivations for visitation, and to investigate the extent to which motivations for visitation affect experience outcomes of the heritage attraction (Fig. 2), this article undertook Partial Least Squares-Structural Equation Modeling (PLS-SEM) analysis using SmartPLS (Hair, Hult, Ringle, \& Sarstedt, 2017). Mikulić and Ryan (2018) provided a critical review of PLS-SEM compared to the more commonly used Covariance-Based SEM (CB-SEM). PLS-SEM "creates (a) weighted composites of indicator variables and (b) proxies for constructs with the assumption of a common factor being relaxed" (Mikulić \& Ryan, 2018, p. 465). As such, many of the assumptions that are needed to underpin CB-PLS, such as the normal distributed variables and large sample sizes, are not necessary in PLS-SEM. In tourism research, these assumptions are unlikely to be present. Hence, the PLSSEM approach offers a way to avoid these rigidities. Further, PLS-SEM analysis should be preferred to 
CB-SEM when the focus of the study is on prediction and theory development, as the statistical power of PLS-SEM is always larger than or equal to that of CB-SEM (Reinartz, Haenlein, \& Henseler, 2009). Reinartz et al. (2009) identified a sampling threshold of 100 for PLS-SEM-based analysis. There are $N=119$ samples in this study.

\section{Findings}

When asked their motivation for visiting Highclere Castle, 110 visitors (92.4\%) reported that watching Downton Abbey was the main reason for visiting the heritage attraction. These visitors could be termed specific television drama-induced tourists. A further three visitors could be termed serendipitous television drama-induced tourists as they had seen the series but their viewing had not wakened an interest in visiting the site while six visitors were partially inspired to visit because of the television series. These types of visitors could be classified as general television drama-induced tourists. In total, 97.5\% stated that Downton Abbey had driven them to visit Highclere Castle. Almost all respondents were first-time visitors to Highclere Castle (96.6\%). The most frequently cited information sources about Highclere Castle were the official website $(40.3 \%)$ and other internet pages (39.5\%), followed by word of mouth from friends and relatives $(20.2 \%)$, the television program itself (14.3\%), and magazines or newspapers (12.6\%).

The demographic profile of visitors to Highclere Castle is shown in Table 1. There was a relatively high proportion of females $(69.7 \%)$. There was a bimodal age distribution with a high proportion of young adults, aged 20-29 years old $(26.1 \%)$ and a higher proportion of older visitors 60 years and above $(21.8 \%)$. Visitors tend to have a high level of education as a large majority of them had a college/university or higher degree $(71.4 \%)$.

To identify factors of audience involvement related to visiting a television drama heritage location, this study undertook factor analysis using principle components analysis, using varimax rotation, on the questions relating to audience involvement to examine the underlying structure of these items. The study opted for varimax rotation, assuming the factors are uncorrelated. The justification is
Table 1

Highclere Visitor Profile $(N=119)$

\begin{tabular}{lc}
\hline & Frequency (\%) \\
\hline Gender & $36(30.3 \%)$ \\
Male & $83(69.7 \%)$ \\
Female & \\
Age & $15(12.6 \%)$ \\
Younger than 20 years & $31(26.1 \%)$ \\
20-29 years & $14(11.8 \%)$ \\
30-39 years & $11(9.2 \%)$ \\
40-49 years & $22(18.5 \%)$ \\
50-59 years & $26(21.8 \%)$ \\
60 years or older & \\
Educational attainment & $34(28.6 \%)$ \\
High school or below & $45(37.8 \%)$ \\
College/university degree & $40(33.6 \%)$ \\
Postgraduate degree or higher & \\
Nationality & $61(51.3 \%)$ \\
UK & $30(25.2 \%)$ \\
US & $13(10.9 \%)$ \\
Europe (except UK) & $6(5.0 \%)$ \\
Asia & $5(4.2 \%)$ \\
Oceania & $4(3.4 \%)$ \\
Africa & \\
\hline
\end{tabular}

that, as Field (2000) stated, "the choice of rotation depends on whether there is a good theoretical reason to suppose that the factors should be related or independent" (p. 439). As demonstrated in the literature, three audience involvement factors and four motivations to travel were identified. Further, this study reran the analysis with direct oblimin rotation. With a direct oblimin rotation, the solution remained nearly orthogonal, with the same number of factors extracted. All except one correlation between the factors for these EFA/PCAs were relatively weak. The Kaiser-Meyer-Oklin measure of sampling adequacy (0.86) and Bartlett's test of sphericity $(p<0.00)$ confirmed that the strength of the interrelationships among variables is high. The solution revealed three factors explaining $63.02 \%$ of the variance in total. Factor 1, factor 2, and factor 3 contributed $24.33 \%, 20.58 \%$, and $18.12 \%$ of variance, respectively. Reliability testing was conducted for each of the three factors analysis. The Cronbach's alphas were 0.85 for factor 1 (six items), 0.79 for factor 2 (five items), and 0.78 for factor 3 (three items), all above the frequently cited cut-off of 0.7 (Hair, Black, Babin, \& Anderson, 2010). The results presented in Table 2 show that both factor loadings and communalities met the suggested thresholds. 
The first dimension is labeled "Referential reflection," which contains six items relating to the degree that audiences connect Downton Abbey with their real lives. The second dimension is labeled "Emotional involvement," as it involves five items relating to the degree to which an individual builds emotional relationships with Downton Abbey. The third dimension is labeled "Behavioral involvement" and contains three items referring to the behavior of audience talking about Downton Abbey during and after exposure.
Table 3 lists 25 reasons why audiences might travel to a television drama setting and their corresponding means and standard deviations for those who had viewed Downton Abbey before visiting Highclere Castle. The top five mean scores were motivated to (1) to see the scenery and landscape in real life (4.4), (2) to have a satisfying tourism experience (4.2), (3) to get first-hand experience with Downton Abbey (4.0), (4) to add something special to my holiday (3.9), and (5) to get a sense of Downton Abbey's atmosphere (3.9).

Table 2

Dimensions of Audience Involvement to Highclere Castle

\begin{tabular}{|c|c|c|c|c|c|}
\hline & \multirow[b]{2}{*}{ Mean $(S D)$} & \multicolumn{3}{|c|}{ Factor Loadings } & \multirow[b]{2}{*}{ Communalities } \\
\hline & & Factor 1 & Factor 2 & Factor 3 & \\
\hline \multicolumn{6}{|l|}{ Referential reflection (Dimension 1) } \\
\hline $\begin{array}{l}\text { I felt that DA presented things as they really } \\
\text { were in life. }\end{array}$ & $3.3(1.11)$ & 0.80 & & & 0.66 \\
\hline $\begin{array}{l}\text { I felt that DA portrayed real life lessons and } \\
\text { practices that I could personally relate to. }\end{array}$ & $2.9(1.11)$ & 0.79 & & & 0.67 \\
\hline $\begin{array}{l}\text { DA seemed to understand and cover the kinds } \\
\text { of issues that I wanted to know more about. }\end{array}$ & $3.4(1.00)$ & 0.73 & & & 0.58 \\
\hline $\begin{array}{l}\text { When watching DA, I felt that I was a part of } \\
\text { the story. }\end{array}$ & $2.5(1.13)$ & 0.63 & & & 0.57 \\
\hline $\begin{array}{l}\text { I felt that the DA and my favorite character(s)/ } \\
\text { actor(s) kept me company. }\end{array}$ & $2.4(1.13)$ & 0.60 & & & 0.71 \\
\hline $\begin{array}{l}\text { I found my favorite character(s)/actor(s) in DA } \\
\text { to be attractive. }\end{array}$ & $3.7(0.89)$ & 0.58 & & & 0.55 \\
\hline \multicolumn{6}{|l|}{ Emotional involvement (Dimension 2) } \\
\hline $\begin{array}{l}\text { I looked forward to watching DA and my } \\
\text { favorite character(s)/actor(s) in each episode. }\end{array}$ & $4.2(0.81)$ & & 0.83 & & 0.72 \\
\hline $\begin{array}{l}\text { If there was a story about DA or my favorite } \\
\text { character(s)/actor(s) in newspaper, internet, or } \\
\text { magazine, I would read it. }\end{array}$ & $3.7(1.09)$ & & 0.75 & & 0.64 \\
\hline $\begin{array}{l}\text { I felt sad for my favorite character(s)/actor(s) } \\
\text { when bad things happened to them. }\end{array}$ & $3.9(0.92)$ & & 0.74 & & 0.64 \\
\hline $\begin{array}{l}\text { If my favorite character(s)/actor(s) in DA } \\
\text { appeared on another program, I would watch } \\
\text { that program. }\end{array}$ & $3.6(0.96)$ & & 0.54 & & 0.41 \\
\hline $\begin{array}{l}\text { I arranged my daily/weekly schedule around } \\
\text { DA so as to have a regular relationship with } \\
\text { the program. }\end{array}$ & $2.8(1.30)$ & & 0.53 & & 0.59 \\
\hline \multicolumn{6}{|l|}{ Behavioral involvement (Dimension 3) } \\
\hline $\begin{array}{l}\text { I compared the characters in DA with someone } \\
\text { I know. }\end{array}$ & $2.7(1.21)$ & & & 0.85 & 0.75 \\
\hline $\begin{array}{l}\text { My favorite character(s)/actor(s) in DA are like } \\
\text { my friends. }\end{array}$ & $2.4(1.10)$ & & & 0.79 & 0.76 \\
\hline $\begin{array}{l}\text { I sometimes made remarks to my favorite } \\
\text { character(s)/actor(s) while watching DA. }\end{array}$ & $3.2(1.27)$ & & & 0.66 & 0.58 \\
\hline Eigenvalues & & & 5.96 & 1.51 & 1.36 \\
\hline$\%$ of Variance (total: 63.02 ) & & & 24.33 & 20.58 & 18.12 \\
\hline Reliability coefficient (Cronbach's alpha) & & & 0.85 & 0.79 & 0.78 \\
\hline
\end{tabular}

Note. Items measured on a 5-point Likert scale. DA = Downton Abbey. 
Table 3

Television Drama-Induced Tourism Motivations

\begin{tabular}{|c|c|c|}
\hline Rank & Items & Mean $(S D)$ \\
\hline 1 & To see the scenery and landscape in real life & $4.4(0.72)$ \\
\hline 2 & To have a satisfying tourism experience & $4.2(0.66)$ \\
\hline 3 & To get first-hand experience with DA & $4.0(0.91)$ \\
\hline 4 & To add something special to my holiday & $3.9(0.96)$ \\
\hline 5 & To get a sense of DA's atmosphere & $3.9(1.02)$ \\
\hline 6 & To have fun and feel entertained & $3.9(0.93)$ \\
\hline 7 & To experience something novel and new & $3.8(0.91)$ \\
\hline 8 & To have a unique experience & $3.7(1.07)$ \\
\hline 9 & To feel the romance and nostalgia of DA & $3.7(0.97)$ \\
\hline 10 & To take photos at the site of DA & $3.7(1.12)$ \\
\hline 11 & To talk about it when I returned home & $3.6(1.06)$ \\
\hline 12 & To escape from the ordinary & $3.6(0.95)$ \\
\hline 13 & To make a personal connection with DA & $3.6(1.00)$ \\
\hline 14 & To bring DA to life (make it real) & $3.5(1.11)$ \\
\hline 15 & To personally experience storyline of DA & $3.4(1.04)$ \\
\hline 16 & To go to famous places friends haven't been to & $3.1(1.34)$ \\
\hline 17 & To make a pilgrimage to the site seen on DA & $3.1(1.26)$ \\
\hline 18 & To bathe in the glory of having been here & $3.1(1.32)$ \\
\hline 19 & To relive scenes from DA & $2.9(1.34)$ \\
\hline 20 & To experience personal growth by visiting the site & $2.9(1.21)$ \\
\hline 21 & To fulfill a personal dream & $2.8(1.35)$ \\
\hline 22 & To feel close to my favorite character(s)/actor(s) in DA & $2.7(1.28)$ \\
\hline 23 & To buy memorabilia/souvenirs of DA & $2.7(1.27)$ \\
\hline 24 & To fantasize I was in DA & $2.5(1.27)$ \\
\hline 25 & To fantasize that I was an actor/actress in DA & $2.5(1.20)$ \\
\hline
\end{tabular}

Note. Items measured on a 5-point Likert scale. DA = Downton Abbey.

Examining the underlying structure of the tourists' motivations for travel, an exploratory principle component analysis (PCA) with a varimax rotation was employed. The KMO measure of sampling adequacy for this PCA was 0.91 and Bartlett's test of sphericity was statistically significant $(p<0.00)$, which indicates the correlation matrix is appropriate for conducting a PCA on tourists' motivations. The 25 items can be reduced to a four-factor solution that accounts $65.24 \%$ of the total variance. Table 4 summarizes the results of the PCA. Reliability tests were conducted for each of the four factors. The results of these tests demonstrate that the factors extracted exhibit internal consistency.

The four dimensions were named: "Prestige" (dimension 1), "Personalization" (dimension 2), "Fantasy" (dimension 3), and "Novelty" (dimension 4). The first dimension "Prestige" has nine items loading highly and refers to the inherent status symbol of television drama-induced tourists. This factor accounts for $20.26 \%$ of the variance. The second dimension "Personalization" has six items with high factor loadings. This dimension relates viewers' personal connection with Downton Abbey. Factor 2 accounts for $15.86 \%$ of the variance. The third dimension "Fantasy" refers to fantasy aspects of visiting Highclere Castle. Four items load highly on this dimension and it accounts for $15.04 \%$ of the total variance. The fourth dimension named "Novelty" has six items loading on it. This factor refers to the unique or novelty experience by visiting Highclere Castle. This factor accounts for $14.08 \%$ of the variance.

Visitors to Highclere Castle's rating of their experience are shown in Table 5. A large proportion of visitors to Highclere Castle stated that the visit was well worth the time and effort and they were 
Table 4

Dimensions of Travel Motivation to Highclere Castle

\begin{tabular}{|c|c|c|c|c|c|c|}
\hline & \multirow[b]{2}{*}{ Mean (SD) } & \multicolumn{4}{|c|}{ Factor Loadings } & \multirow[b]{2}{*}{ Communalities } \\
\hline & & Factor 1 & Factor 2 & Factor 3 & Factor 4 & \\
\hline \multicolumn{7}{|l|}{ Prestige (Dimension 1) } \\
\hline To talk about it when I returned home & $3.6(1.06)$ & 0.77 & & & & 0.70 \\
\hline To buy memorabilia/souvenirs of DA & $2.7(1.27)$ & 0.72 & & & & 0.68 \\
\hline To bathe in the glory of having been here & $3.2(1.32)$ & 0.70 & & & & 0.73 \\
\hline To go to famous places friends haven't been to & $3.1(1.34)$ & 0.66 & & & & 0.65 \\
\hline To fulfill a personal dream & $2.8(1.35)$ & 0.64 & & & & 0.67 \\
\hline To experience personal growth by visiting the site & $2.9(1.21)$ & 0.64 & & & & 0.59 \\
\hline To take photos at the site of DA & $3.7(1.12)$ & 0.62 & & & & 0.51 \\
\hline To make a pilgrimage to the site seen on DA & $3.1(1.26)$ & 0.62 & & & & 0.70 \\
\hline To relive scenes from DA & $2.9(1.34)$ & 0.59 & & & & 0.72 \\
\hline \multicolumn{7}{|l|}{ Personalization (Dimension 2) } \\
\hline To make a personal connection with DA & $3.6(1.00)$ & & 0.76 & & & 0.80 \\
\hline To get first-hand experience with DA & $4.0(0.91)$ & & 0.68 & & & 0.62 \\
\hline To have a satisfying tourism experience & $4.2(0.66)$ & & 0.68 & & & 0.53 \\
\hline To bring DA to life (make it real) & $3.5(1.11)$ & & 0.64 & & & 0.64 \\
\hline To feel the romance and nostalgia of DA & $3.7(0.97)$ & & 0.63 & & & 0.58 \\
\hline To add something special to my holiday & $3.9(0.96)$ & & 0.58 & & & 0.45 \\
\hline \multicolumn{7}{|l|}{ Fantasy (Dimension 3) } \\
\hline To fantasize I was in DA & $2.5(1.27)$ & & & 0.82 & & 0.83 \\
\hline $\begin{array}{l}\text { To feel close to my favorite character(s)/actor(s) } \\
\text { in DA }\end{array}$ & $2.7(1.28)$ & & & 0.79 & & 0.83 \\
\hline To fantasize that I was an actor/actress in DA & $2.5(1.12)$ & & & 0.79 & & 0.72 \\
\hline To personally experience storyline of DA & $3.4(1.04)$ & & & 0.53 & & 0.59 \\
\hline \multicolumn{7}{|l|}{ Novelty (Dimension 4) } \\
\hline To have a unique experience & $3.7(1.07)$ & & & & 0.76 & 0.72 \\
\hline To have fun and feel entertained & $3.9(0.93)$ & & & & 0.75 & 0.63 \\
\hline To experience something novel and new & $3.8(0.91)$ & & & & 0.68 & 0.70 \\
\hline To escape from the ordinary & $3.6(0.95)$ & & & & 0.66 & 0.65 \\
\hline To get a sense of DA's atmosphere & $3.9(1.02)$ & & & & 0.58 & 0.64 \\
\hline To see the scenery and landscape in real life & $4.4(0.72)$ & & & & 0.48 & 0.45 \\
\hline Eigenvalues & & & 11.44 & 1.89 & 1.62 & 1.36 \\
\hline$\%$ of Variance (total: 65.24 ) & & & 20.26 & 15.86 & 15.04 & 14.08 \\
\hline Reliability coefficient (Cronbach’s alpha) & & & 0.90 & 0.84 & 0.85 & 0.82 \\
\hline
\end{tabular}

Note. Items measured on a 5-point Likert scale. DA = Downton Abbey.

very satisfied with their visit. They also perceived Highclere Castle to be better than they expected and much better than other comparable attractions. These four items were aggregated into an "Experience outcome" variable for the PLS-SEM analysis. There is a high level of internal consistency with this construct with a Cronbach's alpha of 0. 90.

This study estimated the structural model shown in Figure 2 using the PLS-SEM method. As suggested by Streukens and Leroi-Werelds (2016), to estimate the statistical significance of the path coefficients, a bootstrapping process was implemented using 1,000 randomly generated subsamples (Table 6). In terms of goodness-of fit, the $R^{2}$ and adjusted $R^{2}$ statistics show that the paths with Prestige, Personalization, and Fantasy have relatively good goodness-of-fits (above $60 \%$ of variance explained) but the paths with Novelty and Experience outcomes have only moderate goodness-of-fit statistics. However, all these goodness-of-fit statistics are larger than 0.10, the satisfactory level suggested by Falk and Miller (1992). Further, all $Q^{2}$ values are positive, which confirms the model's predictive relevance (Chin, 2010), although the first three paths have large size effects, Novelty as a dependent variable has a medium size effect and Experience outcomes has a small size effect.

The results of PLS-SEM analysis provide solid support that all three Audience involvement factors affect the Prestige travel motivation. Thus, hypotheses H1a, H2a, and H3a are supported. Emotional 
Table 5

Experience Outcome of Visit to Highclere Castle

\begin{tabular}{lc}
\hline Experience Outcome & Mean $(S D)$ \\
\hline $\begin{array}{l}\text { How does Highclere Castle, in general, rate } \\
\text { compared to what you expected? }\end{array}$ & $4.1(0.76)$ \\
$\begin{array}{l}\text { Is this visit worth your time and effort? } \\
\text { How would you rate Highclere Castle as } \\
\text { a vacation destination compared to other }\end{array}$ & $4.4(0.68)$ \\
$\begin{array}{l}\text { similar places that you may have visited? } \\
\text { Overall, how satisfied are you with your } \\
\text { visit to Highclere Castle? }\end{array}$ & $4.3(0.79)$ \\
Reliability coefficient (Cronbach's alpha) & 0.90 \\
\hline
\end{tabular}

involvement influences Personalization ( $\mathrm{H} 2 b)$, Referential reflection and Behavioral involvement influenceFantasy (H1c, H3c), and Emotional involvement and Behavioral involvement significantly affect Novelty (H2d, H3d). Thus, hypotheses 1, 2 and 3, which propose that Personalization, Fantasy, and Novelty are influenced by various aspects of audience involvement, are partially supported. The analysis shows that only the Personalization travel motivation significantly affects Experience outcomes (H4b). Hence, hypothesis 4 where travel motivation to visit the television drama-based location is positively related to Experience outcome is partially supported.

\section{Conclusions}

The results of this research indicate the large majority of visitors to Highclere Castle watched Downton Abbey before making their trip. The television drama has stimulated interest in visiting Highclere Castle. This finding verifies past research where television dramas that provide audience with motion pictures, images, accounts, and storylines have a significant impact on viewers' perceptions and mental images of a place, which can enhance the awareness and interest in specific places (H. Kim \& Richardson, 2003). This evokes audiences' interest and motivates visitation to the destination.

The results of this study also demonstrate that television dramas contain a range of " $3 \mathrm{P}$ " pull motivational forces summarized by Macionis (2004), as Place (e.g., to see the scenery and landscape), Performance (e.g., to get a sense of destination's atmosphere), and Personality (e.g., to feel close to their favorite character(s)/actor(s) in the destination). The "3P" pull motivational forces were complemented by a range of internal push drivers, which were categorized into four dimensions: Prestige, Personalization, Fantasy, and Novelty. Three of the dimensions, Prestige, Personalization, and Novelty have been previously highlighted in film-induced tourism motivations by Macionis and Sparks (2009), while Fantasy was identified by Macionis (2004) as one of the motivations for specific film-induced tourists. These push and pull forces work together to motivate audiences to travel. In the case of Downton Abbey, Novelty is a strong motivational factor as three of the top five respondents' motivations belong to this dimension. Novelty is a multidimensional concept that embraces a number of elements ranging from escape from routine, curiosity, adventure, surprise, change of predictability to alleviation of boredom (T. H. Lee \& Crompton, 1992). It is often noted as one of the central motivations that influence tourists (Dimanche \& Havitz, 1994; Pearce, 2005). Macionis (2007) argued that the novelty motivation is particularly strong for specific film-induced tourists as a push factor, and novelty plays an essential part in the destination choice process of this category of tourist.

Visitors with different levels of involvement show different motivations, a finding that implies a multidimensionality to audience involvement, as also noted in previous research from media and communication studies (Sood, 2002; Sood \& Rogers, 2000). Different from other research, cognitively oriented involvement (cognitive interaction/ involvement and critical reflection) was not revealed in the PCA. Cognitive audience interaction/ involvement with television drama did not play a role in constructing and affecting audiences' motivations. This result is consistent with S. Kim (2012a).

The three dimensions of audience involvement (Referential reflection, Emotional involvement, and Behavioral involvement) contribute to Prestige motivation of television drama-induced tourists. This finding stresses the importance of the involvement an audience develops through viewing the television drama in determining an anticipation and expectation of prestige and privilege. Emotional involvement was a substantial contributor to television drama-induced tourists' Personalization 
Table 6

Path Coefficients and Goodness-of-Fit of Structural Model

\begin{tabular}{lccccc}
\hline $\begin{array}{l}\text { Dependent Variable/ } \\
\text { Independent Variables }\end{array}$ & $\begin{array}{c}\text { Path } \\
\text { Coefficients }\end{array}$ & $\begin{array}{c}p \\
\text { Value }\end{array}$ & $R^{2}$ & Adj. $R^{2}$ & $Q^{2}$ \\
\hline Prestige & $0.32^{* *}$ & 0.00 & 0.70 & 0.70 & 0.57 \\
H1a: Referential reflection & $0.28^{* *}$ & 0.00 & & & \\
H2a: Emotional involvement & $0.35^{* *}$ & 0.00 & & & \\
H3a: Behavioral involvement & & & & & \\
Personalization & $0.12^{\text {n.s. }}$ & 0.03 & 0.68 & 0.68 & 0.48 \\
H1b: Referential reflection & $0.72^{* *}$ & 0.00 & & & \\
H2b: Emotional involvement & $0.03^{\text {n.s. }}$ & 0.27 & & & \\
H3b: Behavioral involvement & & & & \\
Fantasy & $0.37^{* *}$ & 0.00 & 0.64 & 0.63 & 0.47 \\
H1c: Referential reflection & $0.09^{\text {n.s. }}$ & 0.14 & & & \\
H2c: Emotional involvement & $0.43^{* *}$ & 0.00 & & & \\
H3c: Behavioral involvement & & & & & \\
Novelty & $0.01^{\text {n.s. }}$ & 0.36 & 0.38 & 0.36 & 0.16 \\
H1d: Referential reflection & $0.32^{* *}$ & 0.00 & & & \\
H2d: Emotional involvement & $0.35^{* *}$ & 0.00 & & & \\
H3d: Behavioral involvement & & & & \\
Experience outcomes & $0.20^{\text {n.s. }}$ & 0.22 & 0.31 & 0.29 & 0.01 \\
H4a: Prestige & $0.40^{*}$ & 0.03 & & & \\
H4b: Personalization & $-0.08^{\text {n.s. }}$ & 0.89 & & & \\
H4c: Fantasy & $0.07^{\text {n.s. }}$ & 0.39 & & & \\
H4d: Novelty & & & & & \\
\hline
\end{tabular}

${ }^{*} p<0.05 ; * * p<0.01$. n.s, not significant.

motivation. This finding can be explained by the fact that this type of involvement involves not only identification, familiarity, empathy, and reflection, but also brings personalized intrinsic meanings to the viewers (Riley et al., 1998). Audiences' personalized emotional attachment to the plot and characters could trigger their behavioral intention to visit a destination setting. Referential reflection and Behavioral involvement contribute to Fantasy motivation, while Behavioral involvement and Emotional involvement have an impact on Novelty motivation.

This article empirically demonstrates that audience's Behavioral, Emotional, and Referential involvement, particularly for the genre of television dramas, play a significant role in examining the travel motivations. This demonstrates that celebrity fan involvement or audience involvement as important drivers for influencing tourism phenomenon (Couldry, 1998; H. Kim \& Richardson, 2003; S. Kim, 2012a; S. Lee et al., 2008). However, in contrast to previous literature, audience involvement impacts the Novelty motivation to a lesser extent. This may be explained by the fact that Novelty is a common motivation for leisure tourists referring to a psychological need of seeking a new experience. Crompton
(1979) suggested that tourists might want to visit a place that was entirely new for them or they had known a lot about. Therefore, Novelty motivation is less likely to be related to the knowledge of the destination gained from the television drama or the level of audience involvement with the television drama.

In terms of experience outcomes, the findings reveal that the Personalization travel motivation significantly impacts tourists' evaluation of their on-site television drama-induced tourism experience. S. Kim (2012b) noted that the television drama provides story and character elements such as the attractiveness of characters, the performance of actors or celebrities, and content and narrative. This has a significant effect on postviewing attitudes and on-site experience. According to S. Kim (2010), audiences tend to reenact actions or scenes from the screen so that they can develop an emotional bond between themselves and the media program. This also expresses a desire for personally experiencing the same sense and emotion in real life, which in turn contributes to symbolic, extraordinary, and memorable tourist experiences.

As defined by Macionis (2004), visitors to Highclere Castle are predominantly specific television 
drama-induced tourists. Specific film tourists actively seek the places depicted on television (Kim, 2012a). These findings contrast with the studies of Di Cesare, D'Angelo, and Rech (2009) and Macionis and Sparks (2009), which showed that film-induced tourism is only an incidental tourism activity. Film is only a secondary motivator for traveling to film locations in that literature. The contrast in these findings may be due to the nature of the screened production. As with S. Kim (2012a), this study focused on a television drama series, whereas the other research examined the cases of a one-off film. The effect of television drama on audiences is possibly different from that of film, considering the longer and repeated exposure, as well as viewing experience of television dramas. Television dramas have a stronger influence on inducing audiences' travel behavior compared to films. Both the present study and S. Kim's study were based on the context of a natural or heritage attraction, rather than a whole destination. As such, the different results may be explained by the different nature and scope of the geographic setting. It may be easier to construct specific brand awareness and image of an attraction than that of a destination, where pull factors are broader. More studies are required to investigate this issue further.

\section{Discussion and Implications}

The current research adds to the existing literature by investigating the causal relationships that exist among audience involvement and travel motivation as well as between travel motivation and experience outcomes. This theoretical model was empirically tested by PLS-SEM using primary data collected at Highclere Castle, the filming location of Downton Abbey, which has become a popular tourism destination. The results shown here demonstrate the simultaneous effects of the multiple dimensions of audience involvement on visiting heritage attractions within the context of television drama-induced tourism. It is also revealed that various travel motivations play different roles in affecting audience's on-site experience.

The article also contributes to the practice of tourism and attraction management. First, by showing that Downton Abbey has been a primary motivator for visiting Highclere Castle, the article demonstrates that heritage attractions can target film-induced tourists through television dramas. By revealing the main motivational factors that drive people to visit a television drama setting, the article can help marketers of heritage attractions to attract specific audiences as well as develop appropriate strategies to enhance tourist satisfaction. Specifically, since Personalization is the main driver of the visitor experience outcomes, heritage attractions where films are set should make a personal connection with the film or television series so that visitors get first-hand experience with the film or television series. This might include making props and icons from the television series accessible so that visitors may relive scenes from the television series. Actors from the television series could be invited to the heritage attraction for a Question \& Answer event or special guest appearance to coincide with an anniversary of the heritage attraction. This would help bring the television series to life and add something special to the tourist experience.

Heritage attractions and other tourist attractions that are used as film sites can leverage the popularity of the film or television dramas in their advertising or on social media marketing. The use of the pictures and videos from the film or television drama in the heritage attraction marketing will trigger memories of the watching the series and prompt potential tourists to referentially reflect on how the television drama series impacted their lives.

In addition, this could also inform heritage management decisions on interpretation methods. Managers can leverage film-induced tourism to attract visitors so that heritage attraction visitors can fantasize about the television series characters as they tour the property and personally experience the storylines (Bąkiewicz et al., 2017). New interpretation methods based on both historical and media-related narratives can be developed that enhance visitor attraction revenues and enrich tourist experiences while maintaining the integrity of the attraction. Examples include activities such as taking photographs to show others when returning home or dressing as the characters to simulate and reenact parts of the film, as well as purchasing souvenirs and collecting mementos of their trips.

The heritage attractions and other tourist attractions that are used as film sites could have special screenings of the film or television drama series in 
the grounds of the attraction or on a special occasion, such as an anniversary. This would drive tourism demand and provide another way that attendees could heighten their tourism/viewing experience.

\section{Limitations and Future Research}

Despite the contributions to the television-induced tourism literature as well as heritage attraction management, this study is subject to several limitations. First, this study focuses on a particular case. Although the findings would be applicable to other heritage attractions, there may be characteristics of Highclere Castle and Downtown Abbey that are not generalizable. Future studies might compare the tourist experience where a heritage attraction is an integral part of the storyline with the tourist experience where a heritage attraction is merely used as a backdrop. As a limitation, the sample size is relatively small. Although acceptable to conduct PLS-SEM analysis to investigate how audience involvement with a television drama affects tourists' motivations for visitation, a larger sample size would provide higher reliability of the results. In addition, the sample is skewed toward females. It is uncertain whether this is a function of the appeal of the television drama or related to the visitor profile of the heritage attraction. As such, there may be an underrepresentation of males. Future studies could compare this study with more male-dominated television dramas.

Further, the majority of the sample comprises domestic tourists with a relatively high level of familiarity and involvement with both the television drama and the heritage attraction. Thus, future research could examine a larger sample with more diversified profile to identify travel motivation influences and the role of television drama among the multitude of influences. As with the gender profile of visitors, it is uncertain whether the high proportion of domestic tourists is more a function of the appeal of the heritage attraction or the location of the television drama.

\section{Acknowledgment}

The authors wish to express their appreciation to Dr. Alkmini Gkritzalifor for her helpful comments.

\section{References}

Bąkiewicz, J., Leask, A., Barron, P., \& Rakić, T. (2017). Management challenges at film-induced tourism heritage attractions. Tourism Planning \& Development, 14(4), 548-566.

Beeton, S. (2001). Lights, camera, re-action. How does filminduced tourism affect a country town? In M. F. Rogers \& Y. M. J. Collins (Eds.), The future of Australia's country towns (pp. 172-183). Bendigo, Australia: Centre for Sustainable Regional Communities, La Trobe University.

Beeton, S. (2005). Film-induced tourism. Clevedon, UK: Channel View.

Buchmann, A., Moore, K., \& Fisher, D. (2010). Experiencing film tourism: Authenticity and fellowship. Annals of Tourism Research, 37(1), 229-248.

Busby, G., \& Klug, J. (2001). Movie-induced tourism: The challenge of measurement and other issues. Journal of Vacation Marketing, 7(4), 316-332.

Chang, D. Y. (2016). A study of TV drama series, cultural proximity and travel motivation: Moderation effect of enduring involvement. International Journal of Tourism Research, 18(4), 399-408.

Chen, F., \& Mele, C. (2017). Film-induced pilgrimage and contested heritage space in Taipei City. City, Culture and Society, 9, 31-38.

Chin, W. W. (2010). How to write up and report PLS analyses. In V. Esposito Vinzi, W. W. Chin, J. Henseler, \& H. Wang (Eds.), Handbook of partial least squares: Concepts, methods and applications (pp. 655-690). Berlin, Germany: Springer.

Connell, J. (2005). Toddlers, tourism and Tobermory: Destination marketing issues and television-induced tourism. Tourism Management, 26(5), 763-776.

Connell, J. (2012). Film tourism-Evolution, progress and prospects. Tourism Management, 33(5), 1007-1029.

Connell, J., \& Meyer, D. (2009). Balamory revisited: An evaluation of the screen tourism destination-tourist nexus. Tourism Management, 30(2), 194-207.

Couldry, N. (1998). The view from inside the 'simulacrum': Visitors' tales from the set of Coronation Street. Leisure Studies, 17(2), 94-107.

Crompton, J. L. (1979). Motivations for pleasure travel. Annals of Tourism Research, 6(4), 408-424.

Croy, W. G., \& Heitmann, S. (2011). Tourism and film. In P. Robinson, S. Heitmann, \& P. Dieke (Eds.), Research themes for tourism (pp. 188-204). Wallingford, UK: CABI Publishing.

Dann, G. (1977). Anomie, ego-enhancement and tourism. Annals of Tourism Research, 4(4), 184-194.

Dann, G. M. S. (1981). Tourist motivation: An appraisal. Annals of Tourism Research, 8(2), 187-219.

Di Cesare, F., D'Angelo, L., \& Rech, G. (2009). Films and tourism: Understanding the nature and intensity of their cause effect relationship. Tourism Review International, 13(2), 103-112.

Dimanche, F., \& Havitz, M. E. (1994). Consumer behavior and tourism: Review and extension of four study areas. Journal of Travel and Tourism Marketing, 3(3), $37-57$. 
Egner, J. (2013, January 3). A bit of Britain where the sun never sets. The New York Times. Retrieved from http:// www.nytimes.com/2013/01/06/arts/television/downtonabbey-reaches-around-the-world.html

Falk, R. F., \& Miller, N. B. (1992). A primer for soft modeling. Akron, $\mathrm{OH}$ : University of Akron Press.

Fernandez-Young, A., \& Young, R. (2008). Measuring the effects of film and television on tourism to screen locations: A theoretical and empirical perspective. Journal of Travel \& Tourism Marketing, 24(2-3), 195-212.

Field, A. (2000). Discovering statistics using SPSS for Windows. Thousand Oaks, CA: Sage Publications.

Game, A. (1991). Undoing the social: Towards a deconstructive sociology. Buckingham, UK: Open University Press.

Giles, D. C. (2002). Parasocial interaction: A review of the literature and a model for future research. Media Psychology, 4(3), 279-305.

Gjorgievski, M., \& Trpkova, S. M. (2012). Movie induced tourism: A new tourism phenomenon. UTMS Journal of Economics, 3(1), 97-104.

Gkritzali, A., Lampel, J., \& Wiertz, C. (2016). Blame it on Hollywood: The influence of films on Paris as product location. Journal of Business Research, 69(7), 2363-2370.

Goossens, C. (2000). Tourism information and pleasure motivation. Annals of Tourism Research, 27(2), 301-321.

Hair, J. F., Black, W. C., Babin, B. J., \& Anderson, R. E. (2010). Multivariate data analysis (7th ed.). Upper Saddle River, NJ: Prentice Hall.

Hair, J., Hult, G., Ringle, C., \& Sarstedt, M. (2017). A primer on partial least squares structural equations modeling (PLS-SEM) (2nd ed.). Los Angeles, CA: SAGE.

Hall, C. M., \& Page, S. J. (2006). The geography of tourism and recreation ( $3 \mathrm{rd}$ ed.). London, UK: Routledge.

Havitz, M. E., \& Dimanche, F. (1990). Propositions for testing the involvement construct in recreational and touristic contexts. Leisure Sciences, 12, 179-195.

Hobson, D. (2003). Soap opera. Cambridge, UK: Polity Press.

Iwashita, C. (2006). Media representation of the UK as a destination for Japanese tourists: Popular culture and tourism. Tourist Studies, 6(1), 59-77.

Iwashita, C. (2008). Roles of films and television dramas in international tourism: The Case of Japanese tourists to the UK. Journal of Travel \& Tourism Marketing, 24(2), 139-151.

Jewell, B., \& McKinnon, S. (2008). Movie tourism-A new form of cultural landscape? Journal of Travel \& Tourism Marketing, 24(2-3), 153-162.

Kim, H., \& Richardson, S. L. (2003). Motion picture impacts on destination images. Annals of Tourism Research, 30(1), 216-237.

Kim, J., \& Rubin, A. M. (1997). The variable influence of audience activity on media effects. Communication Research, 24(2), 107-135.
Kim, S. (2010). Extraordinary experience: Re-enacting and photographing at screen-tourism locations. Tourism and Hospitality Planning \& Development, 7(1), 59-75.

Kim, S. (2012a). Audience involvement and film tourism experiences: Emotional places, emotional experiences. Tourism Management, 33(2), 387-396.

Kim, S. (2012b). The impact of TV drama attributes on touristic experiences at film tourism destinations. Tourism Analysis, 17(5), 573-585.

Kim, S., \& Long, P. (2012). Touring TV soap operas: Genre in film tourism. Research Tourist Studies, 12(2), 173-185.

Kim, S., Long, P., \& Robinson, M. (2009). Small screen, big tourism: The role of popular Korean television dramas in South Korean tourism. Tourism Geographies, 11(3), 308-333.

Kim, S., \& O'Connor, N. (2011). A cross-cultural study of screen-tourists' profiles. Worldwide Hospitality and Tourism Themes, 3(2), 141-158.

Kim, S. S., \& Kim, S. (2018). Perceived values of TV drama, audience involvement, and behavioral intention in film tourism. Journal of Travel \& Tourism Marketing, 35(3), 259-272.

Leask, A., Barron, P., \& Fyall, A. (2013). Generation Y: Opportunity or challenge - strategies to engage generation Y in the UK attractions' sector. Current Issues in Tourism, 16(1), 17-46.

Lee, S., \& Bai, B. S. (2016). Influence of popular culture on special interest tourists' destination image. Tourism Management, 52, 161-169.

Lee, S., Scott, D., \& Kim, H. (2008). Celebrity fan involvement and destination perceptions. Annals of Tourism Research, 35(3), 809-832.

Lee, T. H., \& Crompton, J. (1992). Measuring novelty seeking in tourism. Annals of Tourism Research, 19, $732-751$.

Leighton, D. (2007). Step back in time and live the legend: Experiential marketing and the heritage sector. NVSM International Journal of Nonprofit and Voluntary Sector Marketing, 12(2), 117-125.

Lukinbeal, C., \& Zimmermann, S. (2006). Film geography: A new subfield (Filmgeographie: ein neues Teilgebiet). Erdkunde, 60(4), 315-325.

Macionis, N. (2004). Understanding the film induced tourist. Paper presented at the 1st International Tourism and Media Conference, Melbourne, Australia.

Macionis, N. (2007). Film induced tourism: The role of film as a contributor to the motivation to travel to a destination (Ph.D. thesis). University of Griffith, Australia.

Macionis, N., \& Sparks, B. (2009). Film-induced tourism: An incidental experience. Tourism Review International, 13(2), 93-101.

Mikulić, J., \& Ryan, C. (2018). Reflective versus formative confusion in SEM based tourism research: A critical comment. Tourism Management, 68, 465-469.

Pearce, P. (2005). Tourist behaviour: Themes and conceptual schemes. Clevedon, UK: Channel View. 
Pratt, S. (2009). A movie map conversion study: A case study of 'Pride \& Prejudice'. In M. Kozak, J. Gnoth, \& L. Andreu (Eds.), Advances in tourism destination marketing: Managing networks (pp. 59-73). Abingdon, UK: Routledge.

Pratt, S. (2015). The Borat effect: Film-induced tourism gone wrong. Tourism Economics, 21(5), 977-993.

Reijnders, S. (2011). Places of the imagination: Media, tourism, culture. Farnham, UK: Ashgate.

Reinartz, W., Haenlein, M., \& Henseler, J. (2009). An empirical comparison of the efficacy of covariance-based and variance-based SEM. International Journal of Research in Marketing, 26(4), 332-344.

Rewtrakunphaiboon, W. (2009). Film-induced tourism: Inventing a vacation to a location. BU Academic Review, $8(1), 33-42$

Riley, R., Baker, D., \& van Doren, C. S. (1998). Movie-induced tourism. Annals of Tourism Research, 25(4), 919-935.

Riley, R., \& van Doren, C. S. (1992). Movies as tourism promotion: A 'pull factor' in a 'push' location. Tourism Management, 13(3), 267-274.

Saunders, M. (2012). Research methods for business students (6th ed.). Harlow, UK: Pearson.

Schiappa, E., Gregg, P. E., \& Hewes, D. E. (2005). The parasocial contact hypothesis. Communication Monographs, $72(1), 92-115$.

Sekaran, U. (2003). Research methods for business: A skill building approach (4th ed.). New York, NY: John Wiley \& Sons.

Sellgren, E. (2011). Film-induced tourism: The effect films have on destination image formation, motivation and travel behaviour. Saarbrücken, Germany: LAP Lambert Academic Publishing.

Shim, D. (2006). Hybridity and the rise of Korean popular culture in Asia. Media, Culture \& Society, 28(1), 25-44.

Smith, G. M. (2003). Film structure and the emotion system. Cambridge, UK: Cambridge University Press.

Sood, S. (2002). Audience involvement and entertainmenteducation. Communication Theory, 12(2), 153-172.
Sood, S., \& Rogers, E. (2000). Dimensions of parasocial interaction by letter-writers to a popular entertainmenteducation soap opera in India. Journal of Broadcasting \& Electronic Media, 44(3), 386-414.

Streukens, S., \& Leroi-Werelds, S. (2016). Bootstrapping and PLS-SEM: A step-by-step guide to get more out of your bootstrap results. European Management Journal, 34(6), 618-632.

Su, H. J., Huang, Y., Brodowsky, G., \& Kim, H. J. (2011). The impact of product placement on TV-induced tourism: Korean TV dramas and Taiwanese viewers. Tourism Management, 32(4), 805-814.

Tooke, N., \& Baker, M. (1996). Seeing is believing: The effects of film on visitor numbers to screened locations. Tourism Management, 17(2), 87-94.

Tuan, Y.-F. (1974). Topophilia: A study of environmental perception, attitudes, and values. Englewood Cliffs, $\mathrm{NJ}$ : Prentice Hall.

Valaskivi, K. (2000). Being a part of the family? Genre, gender and production in a Japanese TV drama. Media, Culture \& Society, 22(3), 309-325.

Van Raaij, W. F., \& Crotts, J. C. (1994). Introduction: The economic psychology of travel and tourism. Journal of Travel \& Tourism Marketing, 3(3), 1-19.

Visit Britain. (2014). Marketing highlights 2011-2014. Retrieved from https://www.visitbritain.org/sites/default/ files/vb-corporate/Documents-Library/documents/Visit Britain_Marketing_Highlights.pdf

Wong, J. Y., \& Lai, T. C. (2015). Celebrity attachment and behavioural intentions: The mediating role of place attachment. International Journal of Tourism Research, 17(2), 161-170.

Yen, C., \& Teng, H. (2015). Celebrity involvement, perceived value, and behavioral intentions in popular media-induced tourism. Journal of Hospitality and Tourism Research, 39(2), 225-244.

Yildirim, Y., \& Aydın, K. (2012). The role of popular TV series and TV series characters in creating brand awareness. Procedia - Social and Behavioral Sciences, 62, $695-705$. 
